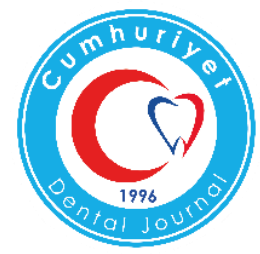

\title{
FORTIFICATION OF FRACTURED INSTRUMENT REMOVAL SIMULATED ROOTS USING SEVERAL CALCIUM SILICATE-BASED MATERIALS
}

\author{
Kırık Enstrüman Çıkartılma Simülasyonu Yapılmış Köklerin Farklı Kalsiyum Silikat \\ İ̧erikli Materyaller Kullanılarak Güçlendirilmesi
}

\author{
Tuğrul ASLAN ${ }^{1}$, Yakup ÜSTÜN${ }^{1}$, Firdevs ÇINAR ${ }^{2}$, \\ Salih DÜZGÜN ${ }^{3}$, İbrahim ŞENER ${ }^{1}$
}

\begin{abstract}
Makale Kodu/Article Code : 391219
Makale Gönderilme Tarihi $\quad$ :06.02.2018

Kabul Tarihi

: 25.04.2018
\end{abstract}

\begin{abstract}
Objectives: The aim of this study was to evaluate the forces required to fracture roots obturated with different calcium silicate - based materials, after applying a fractured instrument removal simulation.
\end{abstract}

Material and Methods: Seventy-five mandibular premolars were selected and decoronated. Then, all root canals were instrumented using Reciproc system. To mimic the root canal anatomy after the removal of a fractured instrument, each canal was enlarged with a size3 Peeso reamer. The specimens were distributed into experimental groups according to the materials used for the root fortification: G1: Negative control, G2: ProRoot MTA, G3: Ortho MTA, G4: Biodentine, G5: Endocem MTA. Then, the teeth were embedded into acrylic blocks. A vertical fracture test was applied, and the fracture loads were recorded. Statistical interpretations were made $(\alpha=0.05)$.

Results: G2, G3, G4, and G5 showed greater fracture resistances than $\mathrm{G} 1 \quad(p<0.05)$. There was no significant difference among G2, G3, G4, and G5 ( $p>0.05$ ).

Conclusions: Any of the tested materials could be chosen to reinforce the root after the removal of a fractured instrument.

Keywords: Biodentine, Endocem MTA, Ortho MTA, ProRoot MTA, Root reinforcing, Seperated instrument removal.
Öz

Amaç: Bu çalışmanın amacı, kırık enstrüman çıkartılması simülasyonu uygulanmasından sonra farklı kalsiyum silikat içerikli materyallerle doldurulmuş kökleri kırmak için gereken kuvvetlerin değerlendirilmesi idi.

Gereç ve Yöntem: 75 adet mandibular premolar diş seçildi ve dekorone edildi. Daha sonra, tüm kök kanalları Reciproc sistemi kullanılarak enstrümante edildi. Kırık enstrüman çıkartılmasının ardından meydana gelen kök kanal anatomisini taklit etmek için herbir kanal 3-numara Peeso frezi ile genişletildi. Örnekler kök güçlendirme işlemi için kullanılan materyallere göre deneysel gruplara dağıtıld1: G1: Negatif kontrol, G2: ProRoot MTA, G3: Ortho MTA, G4: Biodentine, G5: Endocem MTA. Daha sonra, dişler akrilik bloklara gömüldü. Vertikal kırılma testi uygulandı ve kırılma yükleri kaydedildi. İstatistiksel değerlendirmeler yapıld $1(\alpha=0,05)$.

Bulgular: G2, G3, G4 ve G5, G1'den daha yüksek kırılma dirençleri gösterdi $(p<0,05)$. G2, G3, G4 ve G5 arasında istatistiksel olarak anlamlı farklılık yoktu $(p>0,05)$.

Sonuç: Test edilen tüm materyaller, kırık enstrüman çıkartılmasının ardından kök güçlendirilmesi için seçenek olabilirler.

Anahtar Kelimeler: Biodentine, Endocem MTA, Ortho MTA, ProRoot MTA, Kök güçlendirilmesi, Kırılmış enstrüman çıkartılması.

\footnotetext{
${ }^{1}$ Department of Endodontics, Faculty of Dentistry, Erciyes University, Kayseri, Turkey.

${ }^{2}$ Specialist Endodontist, UzmanDent Dental Hospital, Kayseri, Turkey.

${ }^{3}$ Specialist Endodontist, Fatma Kemal Timuçin Oral and Dental Health Hospital, Adana, Turkey.
} 


\section{INTRODUCTION}

The fracturing of endodontic instruments within the root canal system is an unfortunate incident that can jeopardize the outcome of the therapy. ${ }^{1}$ One example is the separation of endodontic files during endodontic treatment, with the exact cause still being a topic of debate. ${ }^{2}$ The prevalence of separated instruments has been reported to range from $0.5 \%-5 \%$ by several researchers. ${ }^{3-5}$ It can lead to treatment failure and may cause anxiety in the patient. $^{6}$ Therefore, the removal of the separated instrument is the most appropriate treatment choice, and is usually recommended when tooth survival has a crucial impact on the postdental procedures. ${ }^{1}$

In general, dentists must create a staging platform in the root canal for better visualization and straight line access to the separated instrument. This process can result in a reduction in the root strength because of the extra removal of the tooth structure and may lead to a vertical root fracture (VRF). ${ }^{7}$ Gerek et al. ${ }^{8}$ examined the force required to lead a VRF after the removal of seperated endodontic instruments and reported that the primary factor for the diminish of root strengths could be related to the staging platform arranging. For this reason, root fortification has become a necessity in such cases.

To replace the missing dentin from a separated instrument removal, alternative filling materials can be used to fortify the root structure. Mineral trioxide aggregate (MTA) is a calcium silicate-based material (CSM) that is commonly used as a repair material in clinics due to its regenerative capabilities, superior seal, and biocompatibility. ${ }^{9}$ However, MTA does have some disadvantages, such as its high price, difficult manipulation attributes, prolonged hardening time, and discoloration potential. ${ }^{9}$

ProRoot MTA (Dentsply, Tulsa Dental, Tulsa, OK, USA) is one of the most widely preferred CSMs for vital endodontic therapies, root perforation repairs, root-end fillings, and apical barriers in immature apices. It consists mainly of tricalcium aluminate, tricalcium oxide, tricalcium silicate, and other oxides that can set in the existence of water. ${ }^{10}$ Ortho MTA (BioMTA, Seoul, Republic of Korea) was developed mainly for orthograde root canal obturation, as well as retrograde fillings and perforation repairs. ${ }^{11}$ It consists of tricalcium aluminate, dicalcium silicate, tricalcium silicate, gypsum, tetracalcium aluminoferrite, bismuth oxide, and free calcium oxide. It also has bioactive characteristics, causing the apical foramen to release calcium ions, which leads to the formation of an interfacial hydroxyapatite layer. ${ }^{11}$ Endocem MTA (Maruchi Co. Ltd., Wonju, Korea) is an MTA-derived pozzolan cement with a chemical composition similar to that of MTA. It consists of aluminum oxide, calcium oxide, silicate oxide, magnesium oxide, and bismuth trioxide ${ }^{12}$, has a clinically faster working time than the other CSMs and has shown good clinical results in vital pulp therapy. ${ }^{10}$ Biodentine (Septodont, Saint-Maurdes-Fosses, France) is another CSM that was introduced to the market to improve MTA's drawbacks. Biodentine powder consists of calcium carbonate, dicalcium silicate, and zirconium oxide as a radiopacifier, in addition to MTA powder. ${ }^{13}$

Within our knowledge, no previous studies have been done before about the effects of CSMs stored in simulated body fluid (SBF) on the fracture resistance of roots that were treated to simulate having apically fractured instruments removed. Hence, the purpose of this study was to detect which repair materials were effective in reinforcing the root after removing the broken instrument from the apical part of the root canal. The null hypothesis was established as there was no significant difference among the tested materials in the means of the fracture resistances.

\section{MATERIALS AND METHODS}

After approval of the local ethics committee (Decision number: 2017/450), seventy-five human maxillary incisor teeth with single and 
straight roots were selected and stored in saline solution until use. To determine the single and straight canal morphologies, buccolingual and mesiodistal radiographs of the specimens were taken. The teeth were inspected under an operating microscope (OPMI pico; Zeiss, Germany) to verify that they had no cracks, resorption, or caries.

The specimens were decoronated with slow speed diamond discs (IsoMet; Buehler, Lake Bluff, IL, USA) under water cooling to obtain a standard root length of $13 \mathrm{~mm}$. The pulp tissue remnants were cleaned ultrasonically, and the patencies of root canals were controlled with 10 K-file (Dentsply Maillefer, Ballaigues, Switzerland). The working length was determined $1 \mathrm{~mm}$ short of the apex and corresponded to $12 \mathrm{~mm}$. The root canal preparations were performed with a Reciproc instrument (VDW, Munich, Germany) (up to size R40) in "Reciproc all mode" using a VDW Silver endodontic motor. After each instrument change, the root canals were irrigated with $2 \mathrm{~mL}$ of $2.5 \% \mathrm{NaOCl}$ solution using 30 -gauge needle. Each canal was enlarged with a size-3 Peeso reamer drill (RelyX, 3M ESPE) up to $3 \mathrm{~mm}$ of the apical root canal. In that way, radicular access to the separated fragment's coronal end was simulated. For the final irrigation, $10 \mathrm{~mL}$ of $5 \%$ $\mathrm{NaOCl}$ and $3 \mathrm{~mL}$ of distilled water were used for each canal. The root canals were dried with absorbent paper points and the apical parts of the root canals were filled with gutta-percha and $\mathrm{AH}$ Plus root canal sealer (Dentsply Maillefer, Ballaigues, Switzerland). The access cavities were sealed with temporary filling material (Cavit G, 3M ESPE, Seefeld, Germany). Then, the teeth were kept at $37^{\circ} \mathrm{C}$ in $100 \%$ humidity for 7 days for complete setting of the root canal sealer.

To simulate the periodontal ligaments, a polyether impression material (Impregum F; 3M ESPE, St. Paul, MN, USA) was used to coat the surface up to $7 \mathrm{~mm}$ from the apex of the root. The teeth were then embedded in plastic tubes filled with self-curing acrylic resin (Imicryl, Konya, Turkey) up to $7 \mathrm{~mm}$ from the apex. Next, the temporary filling materials were removed, and the specimens were randomly divided into 5 groups $(n=15)$. The created spaces were filled with one (or none) of four materials as follows:

Group 1: The coronal part of the root canal was left empty (negative control).

Group 2: ProRoot MTA was prepared according to the manufacturer's recommendations (in a 3:1 powder/liquid ratio). When placing the ProRoot MTA, an MTA carrier was used and the material was gently condensed with a hand plugger (No: 3/4 Machtou plugger; Dentsply Maillefer).

Group 3: Ortho MTA was prepared according to the manufacturer's recommendations and placed into the root canal with its special syringe.

Group 4: Biodentine capsules were mixed for 30 seconds in an amalgam mixer according to the manufacturer's recommendations and placed into the root canal. When placing the Biodentine, an MTA carrier was used and the material was gently condensed with a hand plugger (No: 3/4 Machtou plugger; Dentsply Maillefer).

Group 5: Endocem MTA was prepared according to the manufacturer's recommendations (in a 2:1 powder/liquid ratio) and placed into the root canal.

The acrylic resin blocks with the obturated roots were kept in $100 \%$ humidity in SBF solution for 5 weeks to completely set the filling materials. The root canal orifices were not sealed with the temporary filling material. The ion concentrations of the SBF used in this study are shown in Table 1. After setting, each acrylic mold was placed in a universal testing machine (Instron Corp., Canton, MA, USA) holding a 3$\mathrm{mm}$ diameter round tip, which was placed in contact with the surface of the obturated root canal. The testing machine was moved vertically, with a crosshead speed of $1 \mathrm{~mm} / \mathrm{min}$, 
until a fracture occurred. The loads that lead to fracture was then recorded.

Table 1. Ion concentrations of the simulated body fluid used in this study and human blood plasma.

\begin{tabular}{|l|c|c|c|c|c|c|c|c|}
\hline & \multicolumn{7}{|c|}{ Ion concentrations $(\mathbf{m M})$} \\
\hline & $\mathbf{N a}^{+}$ & $\mathbf{K}^{+}$ & $\mathbf{M g}^{2+}$ & $\mathbf{C a}^{2+}$ & $\mathbf{C l}$ & $\mathbf{H C O}_{3}{ }^{-}$ & $\mathbf{H P O}_{4}{ }^{2-}$ & $\mathbf{S O}_{4}{ }^{2-}$ \\
\hline Human blood plasma & 142.0 & 5.0 & 1.50 & 2.50 & 103.0 & 27.0 & 1.0 & 0.5 \\
\hline Simulated body fluid (SBF) & 142.0 & 5.0 & 1.50 & 2.50 & 103.0 & 27.0 & 1.0 & 0.5 \\
\hline
\end{tabular}

All of the statistical analyses were performed using SPSS 20.0 (IBM Corporation Software Group, Armonk, NY, USA). The ShapiroWilk's test showed that the data were distributed normally; thus, a one-way ANOVA test was applied to the data. Because the Levene's variance homogeneity test failed, Tamhane's T2 test was used for the post-hoc analyses $(\alpha=0.05)$.

\section{RESULTS}

According to the statistical comparisons. Groups 2, 3, 4, and 5 showed significantly greater fracture resistances than Group 1 (negative control) $(p<0.05)$; however, there was no significant difference among these groups $(p>0.05)$. The descriptive statistics of each group are provided in Table 2 and an error bar graph is shown in Figure 1.

Table 2. Descriptive statistics of the tested groups.

\begin{tabular}{|l|c|c|c|c|}
\hline & Mean (Newton) & Std. Deviation & Min. & Max. \\
\hline Negative Control $^{\text {a }}$ & 714.6 & 195.5 & 328.0 & 972.0 \\
\hline ProRoot MTA $^{\text {b }}$ & 1085.1 & 279.8 & 761.1 & 1498.0 \\
\hline Ortho MTA $^{\text {b }}$ & 1032.9 & 309.2 & 666.2 & 1727.2 \\
\hline Biodentine $^{\text {b }}$ & 1049.7 & 306.3 & 583.7 & 1498.1 \\
\hline Endocem MTA $^{\text {b }}$ & 982.3 & 194.4 & 533.0 & 1283.0 \\
\hline
\end{tabular}

*Significantly different groups are shown with different superscript letters.

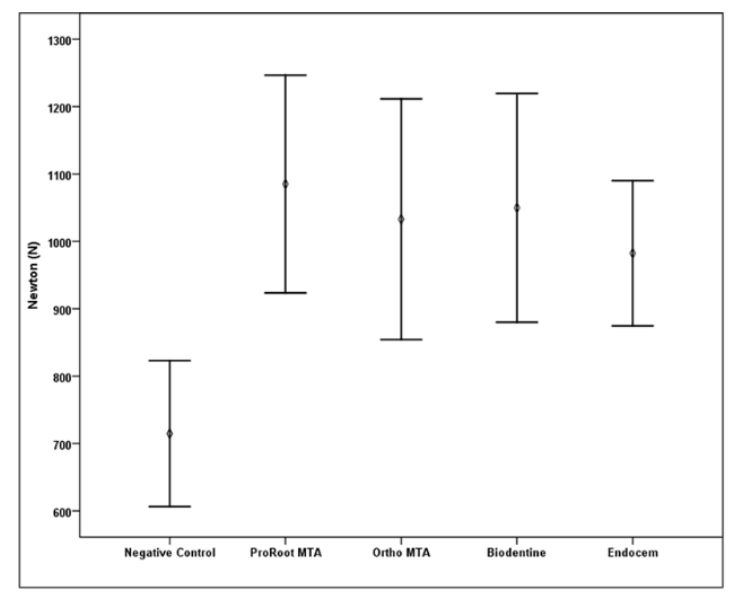

Figure 1. Error bar graph showing the mean values and confidence intervals for the means $(95 \%$ level) of the tested groups.

\section{DISCUSSION}

When a root canal instrument fracture occurs in the apical third of the root canal, excessive removal of the tooth structure also occurs as a result of the fracture removal procedure. ${ }^{14}$ This operation can decrease root strength, ${ }^{7,14}$ which can lead to extraction, amputation, or hemisection procedures. ${ }^{15}$ Some previous studies have found that after the removal of fractured instruments using ultrasonic tips, the fracture resistance of the tooth was reduced because of the greater loss of root dentin in the middle and coronal thirds of the roots. ${ }^{14,16}$ Another system, the Masserann kit (MicroMega, Besancon, France), has rigid and large trepan burs, which remove a considerable amount of dentin tissue while reaching the fractured fragment of an endodontic instrument, further weakening the root. $^{8}$ In this study, a size3 Peeso reamer drill was used to simulate the trepan drills of fractured instrument removal systems like the Masserann kit, and to mimic the excessive root dentin lost in apically located fractured fragment removal cases.

There is some contradictory data in the literature regarding MTA's ability to reinforce weakened teeth. Bortoluzzi et al. ${ }^{17}$ found that MTA reinforces the tooth after 48 hours; however, Hatibovic-Kofman et al. ${ }^{18}$ showed that the strengthening effect could not be achieved until after 1 year of storage. Moreover, Schmoldt et al. ${ }^{19}$ found that MTA did not improve the fracture resistance of weakened roots when compared with an unfilled control. In another study, Elnaghy et al. ${ }^{20}$ indicated that Biodentine did not significantly reinforce the teeth when compared to MTA; however, both the MTA and Biodentine groups showed significantly greater fracture resistance values than those of the unfilled teeth. As in our study, those researchers used a phosphate-containing solution to simulate the clinical conditions. ${ }^{20}$

In this study, the fortification of roots weakened with a simulated fractured instrument removal was investigated using several 
different repair materials. According to the findings of this research, the null hypothesis must be accepted, because there was no statistically significant difference among the tested materials $(p>0.05)$. In addition, groups 2, 3, 4, and 5 showed greater fracture resistances than Group 1 ( $p<0.05$ ), which means that all of the tested repair materials increased the fracture resistance of the roots when compared to the control group. One factor that could have led to these results was the similar moduli of elasticity of the CSMs to that of dentin, which could cause a more homogeneous stress distribution in the root dentin and reduce the chance of fracture..$^{21-23}$

In several studies, it was shown that the use of SBF and phosphate buffered saline (PBS) created an interfacial layer between the dentin and tricalcium silicate cement. ${ }^{13,24}$ The interfacial layer formation mechanism is comprised of the release of $\mathrm{Ca}^{2+}$ ions from the CSMs in the phosphate-containing medium, during and after setting. Afterwards, the amorphous calcium phosphate precipitates and transforms into apatite crystals. ${ }^{25}$ Previous studies have indicated that if the phosphatecontaining solution has an ion concentration equal to or close to that of blood plasma, apatite with a composition and structure that is equal to or close to that of bone apatite will be produced. ${ }^{26,27}$ SBF usage has the advantage of providing conditions similar to those of the body's environment.

The bioactivity and interfacial layer formation between the Biodentine and dentin were shown by Kim et al. ${ }^{13}$, who found that the interfacial layer thickness of Biodentine was lower than that of the ProRoot MTA. The Ortho MTA manufacturer claims that an interfacial layer of hydroxyapatite is created between the Ortho MTA and the canal wall dentin, thus preventing microleakage. ${ }^{11}$ Endocem MTA cement possesses the lower calcium releasing ability of pozzolan-based cements, which might result in decreased calcium/phosphorous proportion precipitates. $^{28}$ Lower fracture resistance values of the Endocem MTA cement could be related to this situation in this study. However, there were no significant differences among the other test materials. The greater fracture resistances of the CSMs than the negative control group, could also be related to the formation of a hydroxyapatite-like layer between the dentin and CSM. ${ }^{29}$ The formation of apatite crystals at the CSM and dentin interface has been associated with the ability to seal and the biocompatibility of the cement, indicating chemical bonding between the dentin and CSM. ${ }^{24}$ The bioactivity of CSMs has been reported to improve the push-out bond strengths of MTA cements because of a strong system of micromechanical bonding to the dentin. ${ }^{25}$ In one previous study, the authors reported that interfacial hydroxyapatite-like layer formation can increase resistance to vertical root fractures in MTA-filled roots. ${ }^{30}$

\section{CONCLUSION}

Within the limitations of this in vitro study, all of the tested materials appear to be good choices for reinforcing the root after the fractured instrument removal from the apical part of the root canal. Further in vivo studies are needed to exactly define the effects of CSMs on root canal treated teeth in their natural conditions.

\section{ACKNOWLEDGEMENTS}

The authors deny any conflicts of interests related to this study.

\section{REFERENCES}

1. Madarati AA, Hunter MJ, Dummer PM. Management of intracanal separated instruments. J Endod 2013;39:569-81.

2. Madarati AA, Watts DC, Qualtrough AJ. Factors contributing to the separation of endodontic files. Br Dent J 2008;204:241-5.

3. Knowles KI, Hammond NB, Biggs SG, Ibarrola JL. Incidence of instrument separation using LightSpeed rotary instruments. J Endod 2006;32:14-6. 
4. Wolcott S, Wolcott J, Ishley D, Kennedy W, Johnson S, Minnich S, et al. Separation incidence of protaper rotary instruments: a large cohort clinical evaluation. J Endod 2006;32:1139-41.

5. Iqbal MK, Kohli MR, Kim JS. A retrospective clinical study of incidence of root canal instrument separation in an endodontics graduate program: a PennEndo database study. J Endod 2006;32:1048-52.

6. Siqueira JF, Jr. Aetiology of root canal treatment failure: why well-treated teeth can fail. Int Endod J 2001;34:1-10.

7. Lertchirakarn V, Palamara JE, Messer HH. Patterns of vertical root fracture: factors affecting stress distribution in the root canal. $\mathrm{J}$ Endod 2003;29:523-8.

8. Gerek M, Baser ED, Kayahan MB, Sunay H, Kaptan RF, Bayirli G. Comparison of the force required to fracture roots vertically after ultrasonic and Masserann removal of broken instruments. Int Endod J 2012;45:429-34.

9. Parirokh M, Torabinejad M. Mineral trioxide aggregate: a comprehensive literature review--Part III: Clinical applications, drawbacks, and mechanism of action. J Endod 2010;36:400-13.

10.Kim M, Yang W, Kim H, Ko H. Comparison of the Biological Properties of ProRoot MTA, OrthoMTA, and Endocem MTA Cements. J Endod 2014;40:1649-53.

11.Lee BN, Son HJ, Noh HJ, Koh JT, Chang HS, Hwang IN, et al. Cytotoxicity of newly developed ortho MTA root-end filling materials. J Endod 2012;38:1627-30.

12. Choi Y, Park SJ, Lee SH, Hwang YC, Yu MK, Min KS. Biological effects and washout resistance of a newly developed fast-setting pozzolan cement. J Endod 2013;39:467-72.

13.Kim JR, Nosrat A, Fouad AF. Interfacial characteristics of Biodentine and MTA with dentine in simulated body fluid. J Dent 2015;43:241-7.
14. Souter NJ, Messer HH. Complications associated with fractured file removal using an ultrasonic technique. J Endod 2005;31:450-2.

15. Moule AJ, Kahler B. Diagnosis and management of teeth with vertical root fractures. Aust Dent J 1999;44:75-87.

16. Madarati AA, Qualtrough AJ, Watts DC. Effect of retained fractured instruments on tooth resistance to vertical fracture with or without attempt at removal. Int Endod J 2010;43:104753.

17.Bortoluzzi EA, Souza EM, Reis JM, Esberard RM, Tanomaru-Filho M. Fracture strength of bovine incisors after intra-radicular treatment with MTA in an experimental immature tooth model. Int Endod $\mathrm{J}$ 2007;40:684-91.

18.Hatibovic-Kofman S, Raimundo L, Zheng L, Chong L, Friedman M, Andreasen JO. Fracture resistance and histological findings of immature teeth treated with mineral trioxide aggregate. Dent Traumatol 2008;24:272-6.

19. Schmoldt SJ, Kirkpatrick TC, Rutledge RE, Yaccino JM. Reinforcement of simulated immature roots restored with composite resin, mineral trioxide aggregate, gutta-percha, or a fiber post after thermocycling. $\mathrm{J}$ Endod 2011;37:1390-3.

20.Elnaghy AM, Elsaka SE. Fracture resistance of simulated immature teeth filled with Biodentine and white mineral trioxide aggregate - an in vitro study. Dent Traumatol 2016;32:116-20.

21.Jefferies S. Bioactive and biomimetic restorative materials: a comprehensive review. Part II. J Esthet Restor Dent 2014;26:27-39.

22.Jefferies SR. Bioactive and biomimetic restorative materials: a comprehensive review. Part I. J Esthet Restor Dent 2014;26:14-26.

23. Schwartz RS, Robbins JW. Post placement and restoration of endodontically treated teeth: a literature review. J Endod 2004;30:289-301. 
24.Sarkar NK, Caicedo R, Ritwik P, Moiseyeva R, Kawashima I. Physicochemical basis of the biologic properties of mineral trioxide aggregate. J Endod 2005;31:97-100.

25.Reyes-Carmona JF, Felippe MS, Felippe WT. Biomineralization ability and interaction of mineral trioxide aggregate and white portland cement with dentin in a phosphatecontaining fluid. J Endod 2009;35:731-6.

26.Kim HM, Kishimoto K, Miyaji F Kokubo T, Yao T, Suetsugu Y, et al. Composition and structure of apatite formed on organic polymer in simulated body fluid with a high content of carbonate ion. J Mater Sci Mater Med. Materials in Medicine 2000;11:421-6.

27. Oyane A, Kim HM, Furuya T, Kokubo T, Miyazaki T, Nakamura T. Preparation and assessment of revised simulated body fluids. $\mathrm{J}$ Biomed Mater Res A 2003;65:188-95.

28.Han L, Kodama S, Okiji T. Evaluation of calcium-releasing and apatite-forming abilities of fast-setting calcium silicate-based endodontic materials. Int Endod J 2015;48:12430.

29.Han L, Okiji T. Bioactivity evaluation of three calcium silicate-based endodontic materials. Int Endod J 2013;46:808-14.

30.AM EL-Ma, Qualtrough AJ, Watts DC. Resistance to vertical fracture of MTA-filled roots. Dent Traumatol 2014;30:36-42.

\section{Corresponding Author}

Dr. Tuğrul ASLAN

Department of Endodontics,

Faculty of Dentistry,

Erciyes University, Kayseri, Turkey.

Tel : : +90 $3522076666-29137$

Fax : +903524380657

E-mail : dr.tugrulaslan@hotmail.com 